\section{Hg standards:}

$\mathrm{HgCl}_{2}=\mathrm{Hg}$ associated with $\mathrm{Fe}_{2} \mathrm{O}_{3}<\mathrm{Hg}$

associated with humic acids $<\mathrm{HgS}$

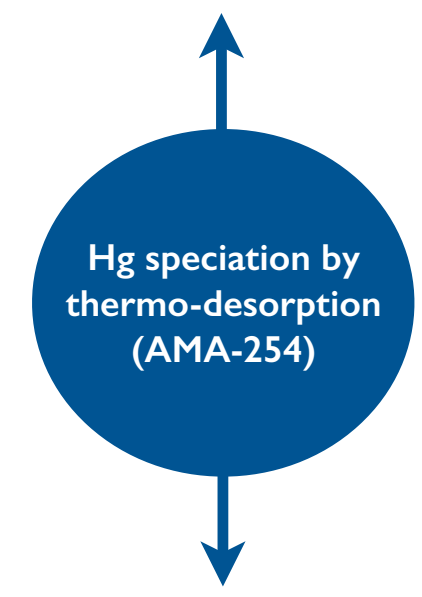

Samples:
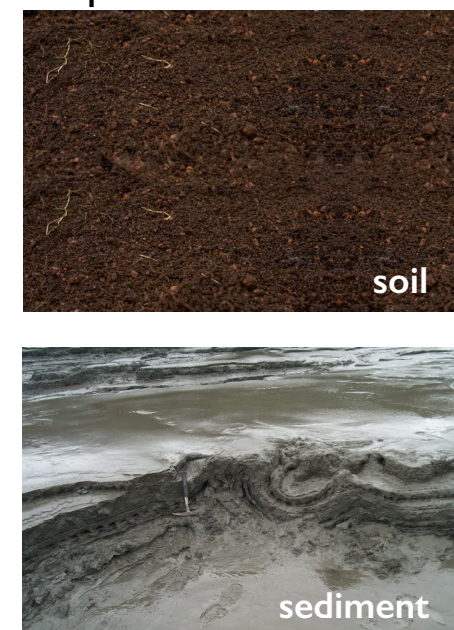

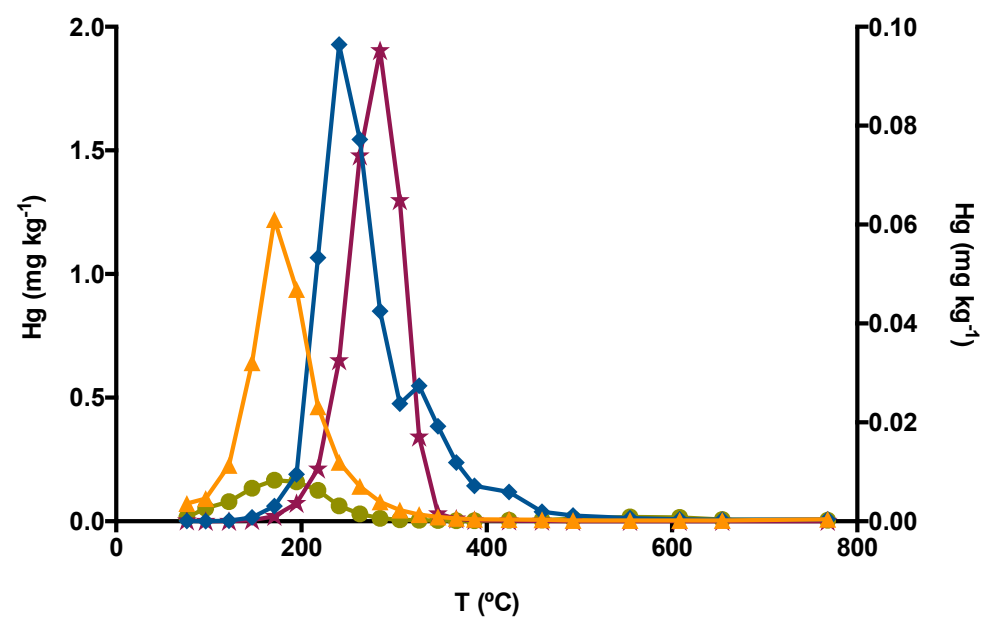

$\pm \mathrm{HgCl}_{2} \star \mathrm{HgS} \nrightarrow \mathrm{HgHA}^{*} \rightleftharpoons \mathrm{Hg}^{*} \mathrm{Fe}_{2} \mathrm{O}_{3}{ }^{*}$

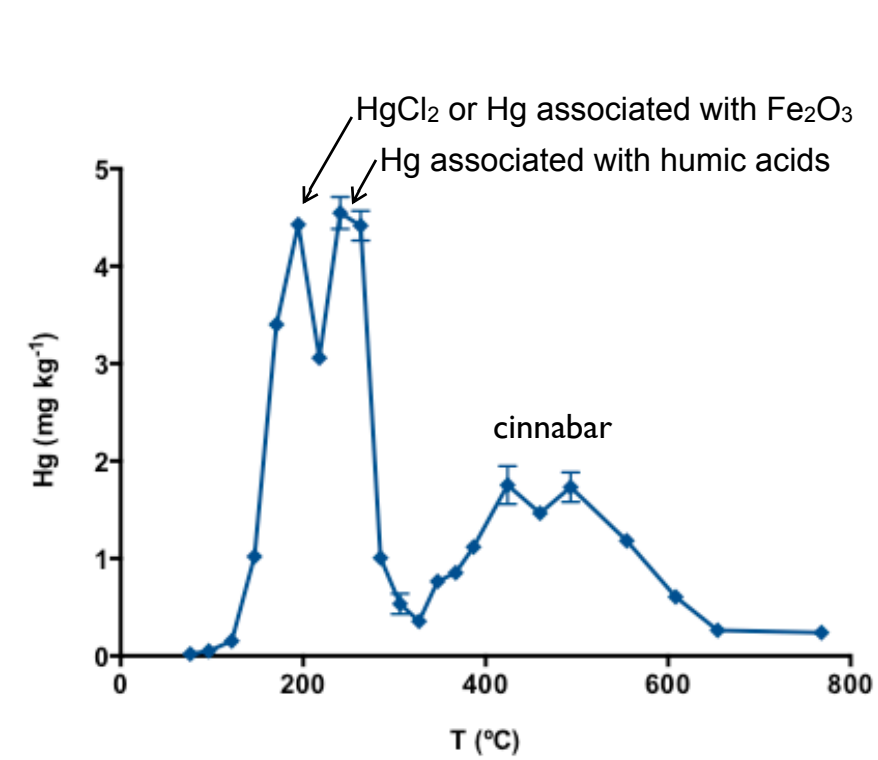


Mercury $(\mathrm{Hg})$ speciation by thermo-desorption is considered an alternative to laborious sequential chemical procedures; hence its popularity has increased in the last years. In this work, steps were taken to improve the information obtained by $\mathrm{Hg}$ speciation through thermo-desorption, specifically to improve peak resolution and increase the number of species that can be identified. The thermo-desorption behaviour of $\mathrm{Hg}$ bound to iron oxides was characterized, as well as a new $\mathrm{Hg}$-humic acids synthetic standard material. In contrast to previous studies, the peak corresponding to the $\mathrm{Hg}$ fraction associated with humic acids was clearly separated from the mineral fraction, and identified in some natural samples. With increasing temperature, $\mathrm{Hg}$ species are released in the following order: $\mathrm{HgCl}_{2}=\mathrm{Hg}$ associated with $\mathrm{Fe}_{2} \mathrm{O}_{3}$ $<\mathrm{Hg}$ associated with humic acids $<\mathrm{HgS}<\mathrm{HgO}$, with an overlap of $\mathrm{HgCl}_{2}$ and $\mathrm{Hg}$ associated with iron oxides.

An evaluation of the effects of sample pre-treatment and storage on $\mathrm{Hg}$ speciation was also performed. It was found that sieving to $<2 \mathrm{~mm}$ improved the sample homogeneity. The importance of fast sample analysis was highlighted, given that after 10 days of storage at room temperature, volatile $\mathrm{Hg}^{0}$ could no longer be identified in the sample. The suitability of thermodesorption for mercury speciation in soils and sediments is discussed. 


\title{
Thermo-desorption: a valid tool for mercury speciation in soils and
} sediments?

Ana Teresa Reis ${ }^{1}$, João Pedro Coelho ${ }^{1}$, Isabel Rucandio ${ }^{2}$, Christine M. Davidson ${ }^{3}$, 5 Armando C. Duarte ${ }^{1}$, Eduarda Pereira ${ }^{1}$

${ }^{2}$ Spectroscopy Unit, Chemistry Division, Technology Department CIEMAT, Avda. Complutense, 4028040 Madrid, Spain

${ }^{3}$ WestCHEM, Department of Pure and Applied Chemistry, University of 13

Strathclyde, 295 Cathedral Street, Glasgow G1 1XL, UK

\section{Corresponding Author: Ana Teresa Reis (teresareis@ua.pt)}

\author{
Phone: +351234 370737
}

Fax: +351234370 084

\section{Abstract}

Mercury $(\mathrm{Hg})$ speciation by thermo-desorption is considered an alternative to laborious sequential chemical procedures; hence its popularity has increased in the last years. In this work, steps were taken to improve the information obtained by $\mathrm{Hg}$ speciation through thermo-desorption, specifically to improve peak resolution and increase the number of species that can be identified. The thermo-desorption behaviour of $\mathrm{Hg}$ bound to iron oxides was characterized, as well as a new $\mathrm{Hg}$-humic acids synthetic standard material. In contrast to previous studies, the peak corresponding to the $\mathrm{Hg}$ fraction associated with humic acids was clearly separated from the mineral fraction, and identified in some natural samples. With increasing temperature, $\mathrm{Hg}$ species are released in the following order: $\mathrm{HgCl}_{2}=\mathrm{Hg}$ associated with $\mathrm{Fe}_{2} \mathrm{O}_{3}<\mathrm{Hg}$ associated with humic acids $<\mathrm{HgS}<\mathrm{HgO}$, with an overlap of $\mathrm{HgCl}_{2}$ and $\mathrm{Hg}$ associated with iron oxides.

2 An evaluation of the effects of sample pre-treatment and storage on $\mathrm{Hg}$ speciation 33 was also performed. It was found that sieving to $<2 \mathrm{~mm}$ improved the sample 
1 homogeneity. The importance of fast sample analysis was highlighted, given that 2 after 10 days of storage at room temperature, volatile $\mathrm{Hg}^{0}$ could no longer be identified in the sample. The suitability of thermo-desorption for mercury speciation in soils and sediments is discussed.

Keywords: Mercury; speciation; thermo-desorption; soil; sediment

\section{$8 \quad 1$ Introduction} problem, in which interest has increased in the past decades due to the growing awareness of the need for risk assessment and remediation of contaminated sites (Ure and Davidson, 2002). Understanding mercury speciation is key for risk assessment of mercury contaminated areas (Bollen et al., 2008) because, even though $\mathrm{Hg}$ is an highly toxic element, its bioavailability, solubility, toxicological, and ecological effects are largely influenced by speciation and the way the different species interact with soil or sediment constituents (Biester et al., 2002a; Clarkson, 2002). These interactions are complex and many chemical, physical and biological processes are involved. These processes are, in turn, dependent on soil and sediment characteristics, especially $\mathrm{pH}$, organic matter, chloride and sulfide content (Biester et al., 2002b; Miretzky et al., 2005). The combination of these factors has, in part, hindered the development of a harmonised protocol for $\mathrm{Hg}$ speciation, despite the fact that this subject has been given considerable attention by several research teams, as is evident in the review provided by Issaro et al. (2009). There are three main approaches to $\mathrm{Hg}$ speciation in soil and sediment: 1) sequential chemical extraction (Fernández-Martínez and Rucandio, 2013; Issaro et al., 2009); 2) X-ray absorption spectroscopy (mainly XAFS and EXAFS) (Kim et al., 2000; Kim et al., 2004); and 3) thermo-desorption (Biester and Scholz, 1997; Reis et al., 2012). Sequential extraction procedures have several known limitations (Bacon and Davidson, 2008), including non-specific removal of $\mathrm{Hg}$ species, as they distribute $\mathrm{Hg}$ content into operationally defined fractions, instead of isolating specific chemical species. Direct measurement of $\mathrm{Hg}$ species by XAFS is possible, but requires total $\mathrm{Hg}$ concentration above $100 \mathrm{mg} \mathrm{kg}^{-1}$, restricting its applicability to contaminated 
1 sites. In the last decades, thermo-desorption has increasingly been used for $\mathrm{Hg}$ 2 speciation in solid matrices (Biester and Scholz, 1997; Bollen et al., 2008; Higueras 3 et al., 2003; Hojdová et al., 2008; Hojdová et al., 2009; Piani et al., 2005; Rallo et al., 4 2010; Rumayor et al., 2013). This technique allows different $\mathrm{Hg}$-binding forms to be distinguished in soils and sediments based on the thermal release of $\mathrm{Hg}$ species. Through comparison with standards, $\mathrm{Hg}$ species can be identified. Although it is a promising technique for $\mathrm{Hg}$ speciation due to its simplicity, there are still some inherent problems that prevent achieving its full potential, such as overlapping peaks (Biester and Scholz, 1997; Reis et al., 2012).

In previous work, described in Reis et al. (2012), an alternative method for $\mathrm{Hg}$ speciation in soils and sediments using a direct mercury analyser for $\mathrm{Hg}$ was presented and its advantages over existing thermo-desorption methods mentioned. The limitations of the approach were discussed as well, namely the difficulty of distinguishing between $\mathrm{HgCl}_{2}$ and $\mathrm{Hg}$ associated with organic matter, due to peak overlap, and also the fact that only a limited range of standard materials were analysed and characterised. Because $\mathrm{Hg}$ behaviour in soil and sediment is complex, and many constituents may act as $\mathrm{Hg}$ sorbents, further method development has been undertaken to try to expand the information that can be obtained. Two new standard materials were considered: $\mathrm{Hg}$ associated with iron (III) oxide $\left(\mathrm{Fe}_{2} \mathrm{O}_{3}\right)$ and $\mathrm{Hg}$ bound to humic acids. The study of $\mathrm{Hg}$-iron oxides complexes in soil and sediment is important due to the role of iron oxides in controling $\mathrm{Hg}$ mobility in these matrices. Humic acids have been considered previously. In the previous work the humic acid-Hg complex was obtained by extraction from a soil sample (Reis et al., 2012) whereas, in this work, a synthetic humic acid sodium salt was used. Thus all standards were of synthetic origin, and their composition known and wellcharacterised.

The applicability of the method was tested by analysing soil and sediment samples with different characteristics and $\mathrm{Hg}$ origins (natural vs. anthropogenic), and a large range of total $\mathrm{Hg}$ content. Additionally the influence of sample pretreatment and time between sampling and analysis were also assessed because it has been reported that common pretreatment procedures such as air-drying, homogenisation, sieving, or storage in plastic bags can be sources of error, particularly in the case of volatile $\mathrm{Hg}^{0}$ that can easily be lost (Rasemann et al., 1995). 


\section{Materials and methods}

\section{$3 \quad 2.1$ Sampling}

4 Samples were collected §at Hg-contaminated sites with known different physico5 chemical characteristics and Hg sources.

Soil samples were collected in Estarreja, North-East Portugal (designated sample Estarreja and another soil sample from this area was used to study the effect of pretreatment and storage), from agricultural fields within a radius of $<1 \mathrm{~km}$ from a chemical industrial complex. For many years this complex was home to a large chlor-alkali plant which formerly produced chlorine and caustic soda using the $\mathrm{Hg}$ cell process, where $\mathrm{Hg}$ was utilized as a cathode in the electrolysis of a saturated brine solution (Ullrich et al., 2007). As other studies show Hg-cell chlor-alkali plants have been identified as major sources of $\mathrm{Hg}$ to the environment (Reis et al., 2009; Ullrich et al., 2007). Until 1975 the liquid effluents from this plant were transported for several kilometres through the agricultural fields surrounding the industrial complex, in man-made effluent streams, and directly discharged in Ria de Aveiro, a nearby coastal lagoon, without any previous treatment.

Another set of soil samples was collected in the Caveira sulfide mine area, SouthEast Portugal (samples Caveira 1 and Caveira 2), which is located in the Iberian Pyrite Belt (IPB), a well-known mining district of worldwide significance, due to its unusual concentration of large and medium sized mineral deposits, including ores of copper, iron, lead, sulfur and zinc. Antimony, arsenic, cadmium, cobalt, gold, mercury, selenium and silver can also be found in soils from the IPB (Barriga, 1990). Past mining activities include pyrite $\left(\mathrm{FeS}_{2}\right)$ and copper $(\mathrm{Cu})$ extraction (Barriga, 1990), resulting in the production of large tailing volumes (estimated to be larger than $2 \mathrm{Mt}$ ) (Cardoso Fonseca and Ferreira da Silva, 2000). Rainwater circulates and percolates easily over and through these tailing materials causing significant erosion and transport of tailings debris to areas nearby and downstream. Recent analysis revealed that soils surrounding the mine have a high mercury content (Rodrigues et al., 2010).

The Almadén mining district (Central Spain) was responsible for one-third of the total world $\mathrm{Hg}$ production and is considered one of the most $\mathrm{Hg}$-contaminated places on Earth, due to its numerous $\mathrm{Hg}$ ore deposits, which have in common a simple 
1 mineralogy that includes dominant cinnabar $(\mathrm{HgS})$ and minor pyrite $\left(\mathrm{FeS}_{2}\right)$ (Higueras 2 et al., 2006). Asturias (Northern Spain) was also a site of abundant mining activities due to the large number of $\mathrm{Hg}$ deposits, in the form of cinnabar, metacinnabar and occasionally native mercury. The abandoned solid waste and industrial installations are still present in agricultural and pastoral fields (Ordóñez et al., 2013). Although these mines are now closed, soil metal contamination and acid mine drainage still pose severe environmental problems at the sites. One sample from each site was analysed (designated samples Almadén and Asturias).

Surface soil samples $(0-15 \mathrm{~cm})$ were collected and transported to the laboratory in plastic bags. After they were air-dried (room temperature less than $20^{\circ} \mathrm{C}$ ), and aggregates crushed, soils were sieved to $<2 \mathrm{~mm}$ using nylon sieves.

Additionally, three replicate cores of estuarine sediment were collected at the Laranjo basin, the most Hg-contaminated area of Ria de Aveiro (Ramalhosa et al., 2006), using a core drill of $7 \mathrm{~cm}$ diameter and $50 \mathrm{~cm}$ depth. The sediment cores were then sliced into $1 \mathrm{~cm}$ layers for vertical profile characterization, the three replicates of each layer depth were combined to create a composite sample, airdried (room temperature less than $20^{\circ} \mathrm{C}$ ), and sieved to $<1 \mathrm{~mm}$ sing nylon sieve.

\subsection{Samples characterisation}

The soil and sediment $\mathrm{pH}\left(\mathrm{CaCl}_{2}\right)$ was determined using a WTW pH meter-538, according to the ISO 10390:1994 method.

For the determination of organic carbon content in soils ( $\mathrm{OrgC}$ ), an excess of 4 mol L ${ }^{-1}$ hydrochloric acid was added to a crucible containing a weighed quantity of soil or sediment in order to remove carbonates. The crucibles were left to stand for 4 hours at room temperature and at 16 hours at $60-70{ }^{\circ} \mathrm{C}$, and the carbon content of the residue was measured on an Elemental Analysis instrument (LECO CNH-2000), according to ISO 10694:1995. Organic matter in sediments was estimated by loss on ignition, placing the sediment in a muffle furnace at $550{ }^{\circ} \mathrm{C}$, until constant weight (approximately 6 hours). The amount of organic matter was estimated by the weight difference between the dry sediment and the remaining ash (Heiri et al., 2001).

Sulfur content (S) was measured on an Elemental Analysis instrument (LECO $\mathrm{CNH}-2000)$. 
The pseudo-total contents of aluminium ( $\mathrm{Al}$ ), iron (Fe), and manganese $(\mathrm{Mn})$ in soils and sediments were extracted by aqua regia, as described in ISO 11466:1995, and analysed by ICP-OES (ICP-OES Jobin Yvon Activa M, Burgener Mira Mist nebulizer), according to ISO $11885: 2007$ ( $2^{\text {nd }}$ edition). The operational conditions used are summarized as follow: RF power: $1200 \mathrm{~W}$; plasma gas flow (argon): $12 \mathrm{~L}$

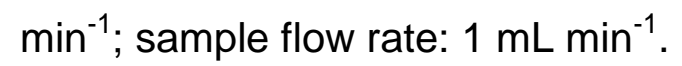

Analytical working range for $\mathrm{Al}$ and $\mathrm{Fe}$ was $0.5-50 \mathrm{mg} \mathrm{L}^{-1}$, and $0.05-10 \mathrm{mg} \mathrm{L}^{-1}$ for Mn. Quantification limits were $0.5 \mathrm{mg} \mathrm{L}^{-1}$ and $0.05 \mathrm{mg} \mathrm{L}^{-1}$, respectively.

Amorphous iron (Fe_ox) and aluminium oxides (Al_ox) were determined by the extraction of $2.5 \mathrm{~g}$ of soil with $50 \mathrm{~mL}$ of a $0.1 \mathrm{~mol} \mathrm{~L}^{-1}$ oxalic acid solution (buffered to $\mathrm{pH} 3$ by ammonium oxalate) and shaken mechanically in the dark for 2 hours. Aluminium and iron contents in the filtered extracts were analysed by ICP-OES (aforementioned operational conditions). Two replicate extractions were performed for each sample. Two extraction blanks were included in each batch of 20 bottles.

The particle size distribution and clay contents of the soil samples were determined using a Coulter LS230 laser diffraction particle size (particle size distribution of Asturias sample was not determined). The classification of soils followed the USDA Texture Classes: sand fraction $(0.050-2 \mathrm{~mm})$, silt fraction $(0.002-$ $0.050 \mathrm{~mm}$ ), and clay fraction $(<0.002 \mathrm{~mm})$. Classification of samples was achieved by using the Talwin $42^{\circledR}$ classification software program. Fine particles $(<63 \mu \mathrm{m})$ of the sediments were determined by wet sieving, by weighing $5 \mathrm{~g}$ of dried sediments (in duplicate) and sieving the sediment through a $63 \mu \mathrm{m}$ sieve under a gentle water flux (Pereira, 1996). The major advantage of this method is the disaggregation of the sediments clusters, formed in the drying process of the sediments, which sometimes it is impossible with the dry sieving. After sieving, the retained fraction $(>63 \mu \mathrm{m})$ was dried at $120^{\circ} \mathrm{C}$ until constant weight and the fraction $<63 \mu \mathrm{m}$ was estimated by the 27 weight difference.

\subsection{Total mercury in soil and sediments}

Total $\mathrm{Hg}$ concentrations were determined by thermal decomposition atomic absorption spectroscopy (AAS) with gold amalgamation (LECO®, model AMA-254) [1]. Briefly, the system consists of a nickel boat carrying the sample into a quartz 
1 decomposition in an oxygen atmosphere, which for total $\mathrm{Hg}$ determination occurs at

$2750^{\circ} \mathrm{C}(150 \mathrm{~s})$. The mercury vapor produced is then trapped on the surface of a gold 3 amalgamator. After a pre-determined time interval (45 s), the amalgamator is heated 4 to $900{ }^{\circ} \mathrm{C}$ to quantitatively release the $\mathrm{Hg}$, which is transported to a heated cuvette $\left(120^{\circ} \mathrm{C}\right)$ prior to analysis by AAS using a silicon diode detector, at $\lambda=253.6 \mathrm{~nm}$.

\subsection{Mercury speciation by thermo-desorption}

Mercury speciation analysis was carried out using the solid fraction thermodesorption technique presented in previous work (Reis et al., 2012). Basically, this method involves the thermal release of $\mathrm{Hg}$ compounds from the matrix, according to their desorption temperatures. Briefly describing the procedure, once the solid sample is placed in the equipment, temperature is increased from $76{ }^{\circ} \mathrm{C}$ to $768{ }^{\circ} \mathrm{C}$ and results are depicted as $\mathrm{Hg}$ thermo-desorption curves (TDC), which show $\mathrm{Hg}$ release $\left(\mathrm{mg} \mathrm{kg}^{-1}\right)$ plotted against temperature $\left({ }^{\circ} \mathrm{C}\right)$. The $\mathrm{Hg}$ species were characterized by the temperature range at which they were released, from the temperature at which thermal-release starts, through the peak maximum, to the point where the curve returns to baseline. Synthetic standard materials were used to identify $\mathrm{Hg}$ species. A detailed description of the development and validation of this technique can be found in Reis et al. (2012).

In the part of this work already published (Reis et al., 2012) the thermal release behaviour of $\mathrm{HgCl}_{2}, \mathrm{Hg}$-humic acids (extracted from a soil) and (red-) $\mathrm{HgS}$ was studied. Two new standard materials were now considered: iron (III) oxide $\left(\mathrm{Fe}_{2} \mathrm{O}_{3}\right)$ from Panreac and humic acid sodium salt, from Sigma Aldrich. Both were purchased in technical grade and no further modifications were made. They were found to have a total $\mathrm{Hg}$ content of 0.045 and $0.26 \mathrm{mg} \mathrm{kg}^{-1}$, respectively.

Each standard or sample was analyzed at least three times, and depending on its total $\mathrm{Hg}$ content, $0.5-40 \mathrm{mg}$ were weighted for each thermo-desorption analysis.

\subsection{Effect of sample pretreatment and storage}

To test the effects that pretreatment and storage may have on $\mathrm{Hg}$ speciation, one soil sample from Estarreja (the sampling location nearest to the laboratory, in order to reduce to minimum the effects of transport) was collected, using the sampling procedure described above, and brought to the laboratory where it was immediately analysed (original sample - day 1). The same sample was then analysed after air- 
1 drying for 24 hours and sieving to $<2 \mathrm{~mm}$ (day 2). This fraction was re-analysed 2 after 5 and 10 days. During this time, the sample was stored in a double plastic bag, 3 at room temperature. This storage procedure was chosen to mimic the typical one used in soil sampling campaigns.

\subsection{Quality control and quality assurance}

Analytical procedures were conducted using ultra-clean glassware (Derquin 5\%, 24 hours; $\mathrm{HNO}_{3} 25 \%, 24$ hours). Care was taken to avoid cross-contamination of the samples.

The accuracy of the LECO AMA-254 was assessed daily by the analysis of certified reference materials BCR-142R and CRM 021 for soil, and MESS-3 and PACS-2 for sediment. Recoveries were within the certified confidence interval and within the range of $82-117 \%$.

\section{Results and discussion}

The thermo-desorption curves (TDC) obtained for standard materials are shown in

Figure 1. A full characterization of the thermo-release behaviour of $\mathrm{HgCl}_{2}$ and synthetic red-HgS can be found in previous work concerning the method development and validation (Reis et al., 2012). In the same work, a standard of $\mathrm{Hg}$ bound to humic acids $(\mathrm{HgHA})$ was considered, with a release peak between 100 and $240 \stackrel{\circ}{ } \mathrm{C}$ that overlapped $\mathrm{HgCl}_{2}$. While that humic acid-Hg complex was obtained by extraction from a soil sample, in the current work synthetic humic acid sodium salt was used. In this case, $\mathrm{Hg}$ thermo-release behaviour occurs between 194 and 424 ${ }^{\circ} \mathrm{C}$ and is characterised by a main peak immediately followed by two smaller peaks (Figure 2). To explain this three-step release behaviour it is important to consider $\mathrm{Hg}^{2+}$-humic acids interaction. Humic acids offer more than one reactive site to which $\mathrm{Hg}^{2+}$ can bind. Mercury will preferetially form covalent bonds with reduced sulfur atoms in reactive sites, hence the overlapping of the second peak with that of $\mathrm{HgS}$. However, as only about $2 \%$ of these sites actively take part in the binding of mercury, they easily become saturated and additional mercury ions have to bind to oxygen- and nitrogen-containing groups, such as phenolic, carboxylic and amine groups (Gismera et al., 2007). The different bound forms have different stability 
1 constants, which lead to the three-step thermo-release of $\mathrm{Hg}$ from humic acids. The 2 comparison of the thermo-desorption curves of soil-extracted and synthetic $\mathrm{HgHA}$

3 (Figure 2) shows the difference between the temperature releases. Humic acids

4 were extracted from soil using $1 \mathrm{~mol} \mathrm{~L}^{-1} \mathrm{HCl}$, which most likely extracted labile species as well; therefore, soil-extracted $\mathrm{HgHA}$ is released at lower temperature than synthetic HgHA.

$\mathrm{Hg}$ associated with iron oxides is mainly released between 100 and $285^{\circ} \mathrm{C}$, while a second, much smaller peak can be observed at 500-610 ${ }^{\circ} \mathrm{C}$. This overlaps with $\mathrm{HgCl}_{2}$. Therefore, it will not be possible to distinguish the two compounds in a natural sample. Still, characterisation of the sample and consideration of its origin may help to infer the species that are most likely present, as will be exemplified below.

\subsection{Soil samples}

Estarreja soil is an acidic silt loam containing $1.7 \%$ organic carbon, $0.65 \%$ iron oxide, and $0.11 \%$ sulfur (Table 1). Thermal-desorption ocurred between 146 and 424 $\stackrel{\circ}{ } \mathrm{C}$ (Figure $3 \mathrm{a}$ ), although $\mathrm{Hg}$ was mainly released in the 146-320 ${ }^{\circ} \mathrm{C}$ temperature interval, which is consistent with $\mathrm{Hg}$ associated with humic acids. This is in accordance with the physical-chemical characterisation of the sample, as the acidic $\mathrm{pH}$ favours the adsorption to organic matter, and this is in higher abundance than the other soil components likely to bind $\mathrm{Hg}$.

Soil sample Caveira 1 shows one major peak at 125-250 ${ }^{\circ} \mathrm{C}$ (Figure $3 \mathrm{~b}$ ), which overlaps $\mathrm{HgCl}_{2}, \mathrm{Hg}$ bound to iron oxides, and $\mathrm{Hg}$ associated with humic acids. This means that $\mathrm{Hg}$ can either be chemically bound to functional groups of organic matter or physically adsorbed to mineral surfaces, but it is difficult to distinguish the species. In fact, both processes can happen, as $\mathrm{Hg}$ (II)-organic complexes may be specifically adsorbed onto the mineral surfaces of the matrix, forming organo-mineral $\mathrm{Hg}$ complexes. The soil characterisation, presented in Table 1, may help to interpret the speciation, as the percentage of iron oxides $(10.42 \%)$ is significantly higher that the percentage of organic matter $(0.51 \%)$. As there is no known possible source of chloride at this location it is likely that $\mathrm{Hg}$ is mainly associeted with iron oxides. There is also evidence of the presence of cinnabar in the 400-600 ${ }^{\circ} \mathrm{C}$ interval.

Soil sample Caveira 2 shows three clearly distinguishable peaks (Figure $3 \mathrm{c}$ ). The first, released at $120-210 \stackrel{\circ}{\circ}$ is consistent with $\mathrm{HgCl}_{2}$ or $\mathrm{Hg}$ bound to iron oxides. The 
second peak suggests the presence of complexes of $\mathrm{Hg}$ with organic matter. The

2 last species that can be identified is possibly cinnabar. Although the TDC does not completely match that of the $\mathrm{HgS}$ standard, it has been reported that $\mathrm{Hg}$ in natural cinnabar is released at higher temperatures when compared to synthetic $\mathrm{HgS}$ (Biester et al., 2000). This is mainly due to the breakdown of the cinnabar lattice, in a process that causes the sudden release of 'pulses' of Hg; hence, decomposition occurs in several steps, which explains the succession of "small peakes".

The thermo-desorption curves for Spanish mine soils from Asturias and Almadén are presented in Figure $4 \mathrm{a}$ and b, respectively. In the Asturias soil, the position of the first peak suggests that $\mathrm{Hg}$ is associated not only with organic matter, but also with iron; cinnabar was also identified in the sample, although in lower concentration. Soil chemical composition corroborates the results of the thermogram, as Asturias soil has $9.9 \%$ of organic matter and $4.3 \%$ of iron, and $0.23 \%$ of sulfur, three strong mercury scavengers.

The $\mathrm{Hg}$ in Almadén soils seems to be present mainly as cinnabar, as would be predicted considering the source of this sample is a former cinnabar mine.

\subsection{Sediment samples}

The total mercury vertical profile of the sediment core collected in Ria de Aveiro is shown inset in Figure 5. The higher concentration between 20 and $30 \mathrm{~cm}$ corresponds to the years of the more pronounced effluent discharges from the chloralkali plant. In order to evaluate differences between top and deeper layers (less and more contaminated layers), some sections were chosen for speciation analysis. The mercury speciation results in the sediment vertical profile indicate that, with exception of section $0-1 \mathrm{~cm}$, thermo-desorption curves have one peak between 140 ${ }^{\circ} \mathrm{C}$ and $280{ }^{\circ} \mathrm{C}$, indicating the occurrence of mercury associated with components such as iron oxides, chloride ions, or organic matter. Sorption of $\mathrm{Hg}^{2+}$ on sediments is a complex process controlled by a number of parameters, such as $\mathrm{pH}$, temperature, mercury concentration, composition of sediment and aqueous media, presence of other cations (e.g. $\mathrm{Fe}^{3+}, \mathrm{Al}^{3+}, \mathrm{Mn}^{2+}, \mathrm{Ca}^{2+}$ ) and anions (such as $\mathrm{S}^{2-}, \mathrm{SO}_{4}{ }^{2-}$

31 ) (Pelcová et al., 2010). Vegetated Ria de Aveiro sediments contain about 20-40\% organic matter and have iron oxide contents that range between 0.50 and $2.6 \%$ 
1 would be solely sorbed to that fraction, but this was not the case. Mercury sorption to sediments is $\mathrm{pH}$-dependent, and the $\mathrm{pH}$ in these sediments is close to neutral, varying from 6.1 to 6.9 (Table 1), which favours sorption to mineral particles (Gabriel and Williamson, 2004). Speciation of the superficial layer $(0-1 \mathrm{~cm})$ also revealed that mercury is mainly present as organic complexes. $\mathrm{HgCl}_{2}$ was not identified, but it can be easily lost to the water column $\left(\mathrm{HgCl}_{2}\right.$ solubility in water is $7.4 \mathrm{~g} / 100 \mathrm{~mL}, \mathrm{~T}=20$ $\left.{ }^{\circ} \mathrm{C}\right)$. Also, mercury sorption to iron oxides is diminished in the presence of chloride ions (Skyllberg, 2010). A second, smaller peak between $400{ }^{\circ} \mathrm{C}$ and $490{ }^{\circ} \mathrm{C}$ was detected in all layers and can be attributed to the presence of mercury oxide (Biester et al., 2000).

\subsection{Effect of sample pretreatment and storage on $\mathrm{Hg}$ speciation}

The effects of sample preatment and storage in $\mathrm{Hg}$ speciation were studied by analysing a soil sample from Estarreja straight from the field (day 1), and then the < $2 \mathrm{~mm}$ fraction after air drying for 24 hours (day 2), 96 hours (day 5), and 10 days (day 10). As the sample was collected in the summer, it air dried in less than 24 hours. Figure 6 shows the thermo-desorption curves for each day after sampling. Surprisingly, a peak below $100{ }^{\circ} \mathrm{C}$ was identified, which should correspond to $\mathrm{Hg}^{0}$ (Biester et al., 2000). This peak has not been observed in previous samples from the same location. All other samples analysed and presented in Reis et al. (2012) and in the current work were stored for longer periods; therefore, $\mathrm{Hg}^{0}$ could have been present in the samples but lost before analysis.

As can be seen in Figure 6, the thermo-desorption curve changes significantly over the 10-day period. The disappearance of the $\mathrm{Hg}^{0}$ peak is noticeable and it is likely that the species is lost during storage, due to its extremely volatile character.

The total $\mathrm{Hg}$ and $\mathrm{Hg}^{0}$ concentrations during the studied period are presented in Table 2. During the 10-day period, almost $32 \%$ of total $\mathrm{Hg}$ were lost, which mainly corresponds to the loss of $\mathrm{Hg}^{0}$ (Table 2). This problem concerns not only $\mathrm{Hg}$ speciation, but also total $\mathrm{Hg}$ determination in soils; often is not possible to analyse samples immediately after sampling and these results show that $\mathrm{Hg}$ concentration can be underestimated due to $\mathrm{Hg}$ losses during sample storage.

Another conclusion that can be drawn from Figure 6 is the higher heterogenity of the original sample, as revealed by the higher standard deviations $(n=4)$. After drying 
1 and sieving, the heterogeneity is reduced, as lower standard deviations were 2 achieved $(\mathrm{n}=4)$. Among the different species, $\mathrm{Hg}^{0}$ has a higher associated standard 3 deviation. One possible explanation for this high heterogeneity may be in the origin 4 of $\mathrm{Hg}^{0}$. While $\mathrm{Hg}$ in soil is mostly present as $\mathrm{Hg}^{2+}$ associated with soil constituents 5 (organic matter, mineral particles), free or weakly bound $\mathrm{Hg}^{2+}$ can be reduced to $\mathrm{Hg}^{0}$ 6 (Robles et al., 2014); being an occasional phenomenon this causes the distribution 7 of $\mathrm{Hg}^{0}$ in the soil to be uneven. Atmospheric deposition can also be considered as a 8 possible origin, since $\mathrm{Hg}^{0}$ emissions are associated with chlor-alkali plants (Biester 9 et al., 2002b) and the presence of heterogeneously distributed $\mathrm{Hg}^{0}$ in the soil (Biester and Scholz, 1997).

It is noteworthy that 10 years after the change of production method from $\mathrm{Hg}$ to membrane-cells in the Estarreja chlor-alkali plant, $\mathrm{Hg}^{0}$ can still be found in the surrounding environment, confirming the persistence of this element in the environment.

\section{Conclusion}

This study allowed some conclusions to be drawn about $\mathrm{Hg}$ speciation in soils and sediments using thermo-desorption. By using only synthetic standards materials, the peak corresponding to $\mathrm{Hg}$ bound to organic matter was able to be separated from other matrix constituents, which seemed a promising improvement in $\mathrm{Hg}$ speciation by this technique. However, when natural samples were analysed, it was still impossible to completely separate all $\mathrm{Hg}$ species. This indicates that thermodesorption cannot be considered a stand-alone tool in $\mathrm{Hg}$ speciation analysis. Knowledge of the physico-chemical characteristics of the sample and of whether $\mathrm{Hg}$ is of geogenic origin or results from anthropogenic input is useful to complement and interpret the results. Samples where $\mathrm{Hg}$ was of geogenic origin showed higher standard deviations between replicates. This was mainly due to the release of $\mathrm{Hg}$ in cinnabar, which involves diffusion from inner-sphere sorption sites during the breakdown of the mineral lattice.

This work also proved that samples stored in plastic bags need to be analysed soon after collection, in order to obtain full information on $\mathrm{Hg}$ speciation. Longer storage periods can result in loss of volatile $\mathrm{Hg}^{0}$. After only 10 days the peak corresponding to $\mathrm{Hg}^{0}$ no longer appeared in thermograms. Sieving to $<2 \mathrm{~mm}$ was 
1 beneficial, as homogenation of the sample was improved. In future experiments 2 different storage and pretreatment conditions will be considered, such as the use of 3 different containers (e.g. amber or glass bottles), and the use of freeze-drying to dry 4 the soil.

5

6

\section{Acknowledgements}

8 This work was supported by European Funds through COMPETE and by National 9 Funds through the Portuguese Foundation for Science and Technology (FCT) within 10 project PEst-C/MAR/LA0017/2013, project SEPMERCURY - Sequential extraction 11 methods for assessing the origin, mobility and toxicity of mercury from contaminated 12 solid matrices and preparation of new sediment and soil reference materials 13 (PTDC/AAC-AMB/105157/2008), and via a PhD grant (SFRH/BD/43681/2008; A.T. 14 Reis). 


\section{References}

Bacon, J.R., Davidson, C.M., 2008. Is there a future for sequential chemical extraction? Analyst, 133(1), 25-46.

Barriga, F., 1990. Metallogenesis of the Iberian Pyrite Belt. In: R.D. Dallmeyer, E. Martinez (Eds.), Pre-mesozoic geology of Iberia. Springer-Verlag, pp. 369379.

Biester, H., Gosar, M., Covelli, S., 2000. Mercury Speciation in Sediments Affected by Dumped Mining Residues in the Drainage Area of the Idrija Mercury Mine, Slovenia. Environ Sci Technol, 34(16), 3330-3336.

Biester, H., Müller, G., Schöler, H.F., 2002a. Binding and mobility of mercury in soils contaminated by emissions from chlor-alkali plants. Sci Total Environ, 284, 191-203.

Biester, H., Müller, G., Schöler, H.F., 2002b. Estimating distribution and retention of mercury in three different soils contaminated by emissions from chlor-alkali plants: part I. Sci Total Environ, 284(1-3), 177-189.

Biester, H., Scholz, C., 1997. Determination of Mercury Binding Forms in Contaminated Soils: Mercury Pyrolysis versus Sequential Extractions. Environ Sci Technol, 31, 233-239.

Bollen, A., Wenke, A., Biester, H., 2008. Mercury speciation analysis in $\mathrm{HgCl}$ contaminated soils and groundwater - Implications for risk assessment and remediation strategies. Water Res, 42, 91-100.

Cardoso Fonseca, E., Ferreira da Silva, E., 2000. Projecto Estudo de Controle Ambiental nas Áreas Mineiras Abandonadas de Lousal e Caveira. Unpublished.

Clarkson, T.W., 2002. The three modern faces of mercury. Environ. Health Perspect., 110, 11-23.

Fernández-Martínez, R., Rucandio, I., 2013. Assessment of a sequential extraction method to evaluate mercury mobility and geochemistry in solid environmental samples. Ecotox. Environ. Safe., 97, 196-203.

Gabriel, M.C., Williamson, D.G., 2004. Principal Biogeochemical Factors Affecting the Speciation And Transport of Mercury through the terrestrial environment. Environ Geochem Hlth, 26(4), 421-434.

Gismera, M.J., Procopio, J.R., Sevilla, M.T., 2007. Characterization of Mercury Humic Acids Interaction by Potentiometric Titration with a Modified Carbon Paste Mercury Sensor. Electroanal., 19(10), 1055-1061.

Heiri, O., Lotter, A.F., Lemcke, G., 2001. Loss-on-ignition as a method for estimating organic and carbonate content in sediments: reproducibility and comparability of results. J. Paleo., 25, 101-110.

Higueras, P., Oyarzun, R., Biester, H., Lillo, J., Lorenzo, S., 2003. A first insight into mercury distribution and speciation in soils from the Almadén mining district, Spain. J. Geochem. Explor., 80(1), 95-104.

Higueras, P., Oyarzun, R., Lillo, J., Sánchez-Hernández, J.C., Molina, J.A., Esbrí, J.M., Lorenzo, S., 2006. The Almadén district (Spain): Anatomy of one of the world's largest Hg-contaminated sites. Sci Total Environ, 356(1-3), 112-124.

Hojdová, M., Navrátil, T., Rohovec, J., 2008. Distribution and Speciation of Mercury in Mine Waste Dumps. Bull Environ Contam Toxicol, 80(3), 237-241. 
Hojdová, M., Navrátil, T., Rohovec, J., Penížek, V., Grygar, T., 2009. Mercury Distribution and Speciation in Soils Affected by Historic Mercury Mining. Water Air Soil Pollut, 200(1-4), 89-99.

Issaro, N., Abi-Ghanem, C., Bermond, A., 2009. Fractionation studies of mercury in soils and sediments: A review of the chemical reagents used for mercury extraction. Anal Chim Acta, 631(1), 1-12.

Kim, C.S., Gordon E. Brown, J., Rytuba, J.J., 2000. Characterization and speciation of mercury-bearing mine wastes using X-ray absorption spectroscopy. 261, 157-168.

Kim, C.S., Rytuba, J.J., Brown, G.E., 2004. EXAFS study of mercury(II) sorption to Fe- and Al-(hydr)oxides: I. Effects of pH. J. Colloid Interf. Sci., 271(1), 1-15.

Miretzky, P., Bisinoti, M.C., Jardim, W.F., Rocha, J.C., 2005. Factors affecting Hg (II) adsorption in soils from the Rio Negro basin (Amazon). Quim Nova, 28, 438443.

Ordóñez, A., Álvarez, R., Loredo, J., 2013. Asturian mercury mining district (Spain) and the environment: a review. Environ Sci Pollut Res, 20, 7490-7508.

Pelcová, P., Margetínová, J., Vaculovič, T., Komárek, J., Kubáň, V., 2010. Adsorption of mercury species on river sediments - effects of selected abiotic parameters. Cent Eur J Chem, 8(1), 116-125.

Pereira, E., 1996. Distribuição, Reactividade e Transporte do Mercúrio na Ria de Aveiro, University of Aveiro, Aveiro, $284 \mathrm{pp}$.

Piani, R., Covelli, S., Biester, H., 2005. Mercury contamination in Marano Lagoon (Northern Adriatic sea, Italy): Source identification by analyses of $\mathrm{Hg}$ phases. 20(8), 1546-1559.

Rallo, M., Lopez-Anton, M.A., Perry, R., Maroto-Valer, M.M., 2010. Mercury speciation in gypsums produced from flue gas desulfurization by temperature programmed decomposition. Fuel, 89(8), 2157-2159.

Ramalhosa, E., Pato, P., Monterroso, P., Pereira, E., Vale, C., Duarte, A.C., 2006. Accumulation versus remobilization of mercury in sediments of a contaminated lagoon. Mar Pollut Bull, 52(3), 353-356.

Rasemann, W., Seltmann, U., Hempel, M., 1995. Statistical evaluation of the influence of several sample pretreatment methods on the mercury content detectable by chemical analysis of contaminated soil samples under practical conditions. Fresen J Anal Chem, 351(7), 632-641.

Reis, A.T., Coelho, J.P., Rodrigues, S.M., Rocha, R., Davidson, C.M., Duarte, A.C., Pereira, E., 2012. Development and validation of a simple thermo-desorption technique for mercury speciation in soils and sediments. Talanta, 99, 363368.

Reis, A.T., Rodrigues, S.M., Araújo, C., Coelho, J.P., Pereira, E., Duarte, A.C., 2009. Mercury contamination in the vicinity of a chlor-alkali plant and potential risks to local population. Sci Total Environ, 407(8), 2689-2700.

Robles, I., Lakatos, J., Scharek, P., Planck, Z., Hernández, G., Solís, S., Bustos, E., 2014. Characterization and Remediation of Soils and Sediments Polluted with Mercury: Occurrence, Transformations, Environmental Considerations and San Joaquin's Sierra Gorda Case. Environmental Risk Assessment of Soil Contamination.

Rodrigues, S.M., Henriques, B., Coimbra, J., Silva, E.F.d., Pereira, M.E., Duarte, A.C., 2010. Water-soluble fraction of mercury, arsenic and other potentially toxic elements in highly contaminated sediments and soils. Chemosphere, 78, 1301-1312. 
Rumayor, M., Diaz-Somoano, M., Lopez-Anton, M.A., Martinez-Tarazona, M.R., 2013. Mercury compounds characterization by thermal desorption. Talanta, 114(0), 318-322.

Skyllberg, U., 2010. Mercury Biogeochemistry in Soils and Sediments. In: S. Balwant, G. Markus (Eds.), Developments in Soil Science. Elsevier, pp. 379410.

Ullrich, S., llyushchenko, M., Kamberov, I., Tanton, T., 2007. Mercury contamination in the vicinity of a derelict chlor-alkali plant. Part I: Sediment and water contamination of Lake Balkyldak and the River Irtysh. Sci Total Environ, 381, $1-16$.

Ure, A.M., Davidson, C.M., 2002. Chemical Speciation in Soils and Related Materials by Selective Chemical Extraction. In: A.M. Ure, C.M. Davidson (Eds.), Chemical Speciation in the Environment. Blackwell Science, London, UK, pp. 265-300. 
Table 1. Soil and sediment samples characterisation.

\begin{tabular}{|c|c|c|c|c|c|c|}
\hline \multicolumn{7}{|c|}{$\begin{array}{l}\text { PORTUGUESE SOIL SAMPLES } \\
\end{array}$} \\
\hline Sample & $\mathrm{Hg}\left(\mathrm{mg} \mathrm{kg}^{-1}\right)$ & $\mathrm{pH}\left(\mathrm{CaCl}_{2}\right)$ & Org C (\%) & $\mathrm{Fe}(\%)$ & Fe_ox (\%) & $S(\%)$ \\
\hline $\begin{array}{l}\text { Estarreja } \\
\text { nare }\end{array}$ & 1.2 & 4.8 & 1.66 & 1.14 & 0.65 & 0.11 \\
\hline Caveira 1 & 6.9 & 3.3 & 0.51 & 4.2 & 10.42 & $<0.05$ \\
\hline Caveira 2 & 34.2 & 2.9 & 0.93 & 6.56 & 11.23 & 0.42 \\
\hline \multicolumn{7}{|c|}{ SPANISH SOIL SAMPLES } \\
\hline Sample & $\mathrm{Hg}\left(\mathrm{mg} \mathrm{kg}^{-1}\right)$ & $\mathrm{pH}\left(\mathrm{CaCl}_{2}\right)$ & Org matter (\%) & $\mathrm{Fe}(\%)$ & S (\%) & sand $(\%)$ \\
\hline Asturias & 153.6 & 6.5 & 9.9 & 4.26 & 0.23 & \\
\hline Almadén & 64.8 & 5.4 & 1.3 & 2.7 & 0.12 & 43.16 \\
\hline \multicolumn{7}{|c|}{ SEDIMENT SAMPLES } \\
\hline Sample depth & $\mathrm{Hg}\left(\mathrm{mg} \mathrm{kg}^{-1}\right)$ & $\mathrm{pH}\left(\mathrm{CaCl}_{2}\right)$ & LOI (\%) & $\mathrm{Fe}(\%)$ & $\mathrm{Fe}_{0} \mathrm{Ox}(\%)$ & Fraction $<0.63 \mu \mathrm{m}(\%)$ \\
\hline Laranjo $_{0-1 \mathrm{~cm}}$ & 8.8 & 6.5 & 41.2 & 3.19 & 1.89 & 33 \\
\hline Laranjo $_{2.3 \mathrm{~cm}}$ & 4.3 & 6.1 & 30.2 & 4.03 & 2.54 & 34 \\
\hline Laranjo $_{5.6 \mathrm{~cm}}$ & 6.3 & 6.1 & 22.5 & 3.56 & 2.56 & 21 \\
\hline Laranjo $_{10-11 \mathrm{~cm}}$ & 5.8 & 6.2 & 28.4 & 3.28 & 2.17 & 26 \\
\hline Laranjo $_{14-15 \mathrm{~cm}}$ & 11.5 & 6.1 & 31.2 & 3.39 & 0.57 & 30 \\
\hline Laranjo $_{20-21 \mathrm{~cm}}$ & 6.9 & 6.2 & 31.3 & 3.47 & 0.56 & 20 \\
\hline Laranjo $_{25-26 \mathrm{~cm}}$ & 50.9 & 6.4 & 32.8 & 4.04 & 0.58 & 32 \\
\hline Laranjo $_{30-31 \mathrm{~cm}}$ & 26.1 & 6.8 & 30.7 & 3.94 & 0.52 & 26 \\
\hline Laranjo $_{38-39 \mathrm{~cm}}$ & 0.7 & 6.9 & 26.4 & 3.15 & 0.50 & 28 \\
\hline
\end{tabular}


Table 2. Evolution of total $\mathrm{Hg}$ and $\mathrm{Hg}^{0}$ concentrations (mean \pm standard deviation; $\mathrm{n}=4$ ) with pretreatment and 10-day storage period.

\begin{tabular}{ccc}
\cline { 2 - 3 } & Total $\mathrm{Hg}\left(\mathrm{mg} \mathrm{kg}^{-1}\right)$ & $\mathrm{Hg}^{0}\left(\mathrm{mg} \mathrm{kg}^{-1}\right)$ \\
\hline Day 1 & $34.2 \pm 2.8$ & $9.5 \pm 4.9$ \\
Day 2 & $32.6 \pm 1.5$ & $6.8 \pm 1.3$ \\
Day 5 & $33.1 \pm 1.5$ & $8.9 \pm 2.0$ \\
Day 10 & $23.4 \pm 0.6$ & $0.05 \pm 0.01$ \\
\hline
\end{tabular}




\section{FIGURE CAPTION}

Figure 1. Thermo-desorption curves (average \pm standard deviation, $\mathrm{n}=10$ ) for $\mathrm{Hg}$ species in synthetic standards materials: mercury chloride $\left(\mathrm{HgCl}_{2}\right)$ and cinnabar $(\mathrm{HgS})$ - left $\mathrm{Y}$ axis; $\mathrm{Hg}$ bound to humic acids $(\mathrm{HgHA})$ and to iron oxides $(\mathrm{HgFe})-$ right $\mathrm{Y}$ axis.

Figure 2. Thermo-desorption curves (average \pm standard deviation, $\mathrm{n}=10$ ) for $\mathrm{Hg}$ bound to humic acids: HgHA extracted from a soil (blue) (Reis et al., 2012) and synthetic (green).

Figure 3. Thermo-desorption curves of Portuguese soils (average \pm standard deviation, $n=3$ ). a) Industrial soil of Estarreja; b) Mine soil of Caveira 1; c) Mine soil of Caveira 2.

Figure 4. Thermo-desorption curves of Spanish mine soils (average \pm standard deviation, $n=3$ ). a) Asturias; b) Almadén.

Figure 5. Thermo desorption curves of Ria de Aveiro sediments vertical profile (average \pm standard deviation, $\mathrm{n}=3$ ). Inset: total $\mathrm{Hg}$ concentration of the profile.

Figure 6. Thermo-desorption curve (average \pm standard deviation, $n=4$ ) of a soil sample where the effects of sample pretreatment and storage can be observed. 
Figure 1

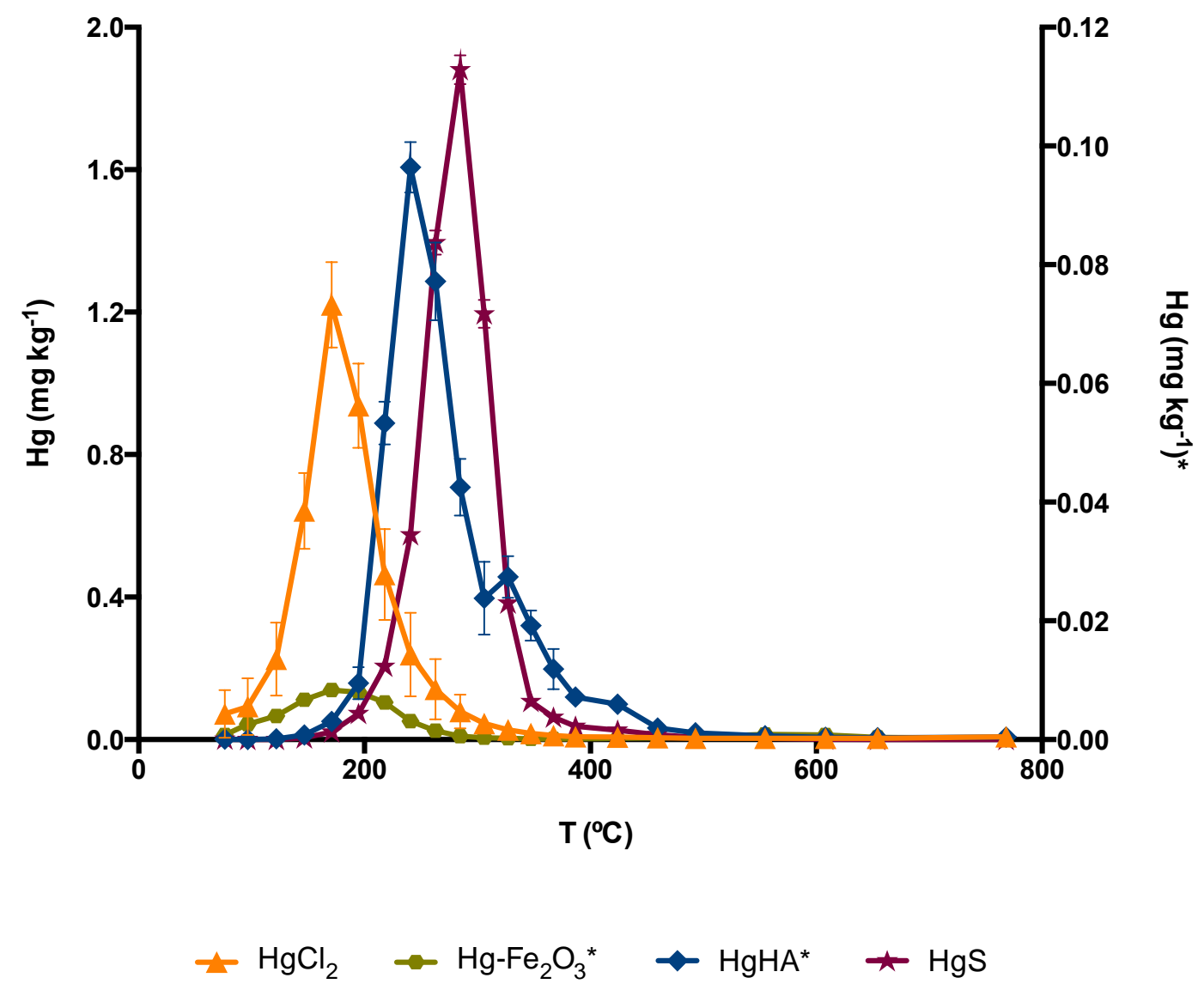


Figure 2

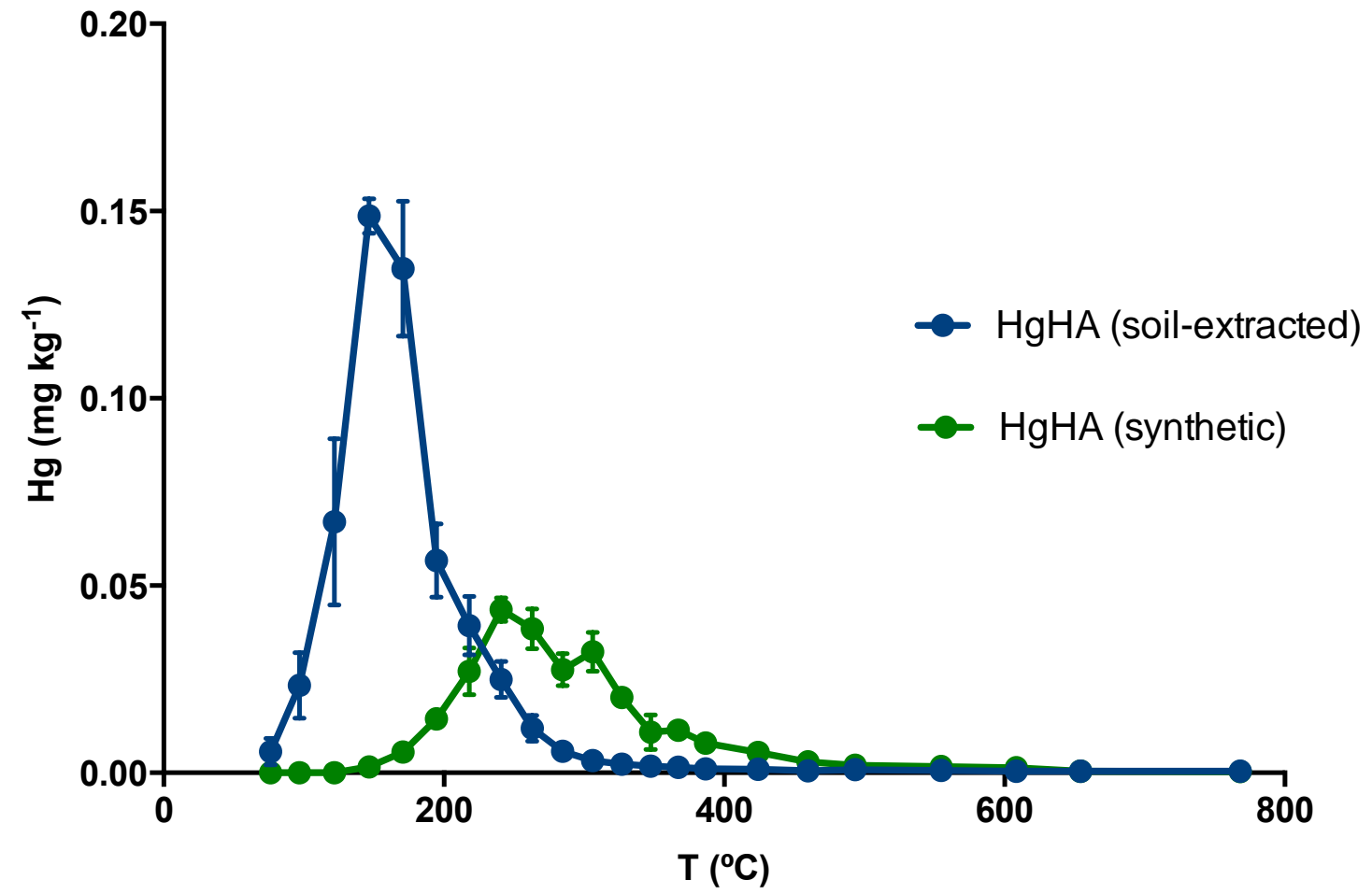


Figure 3
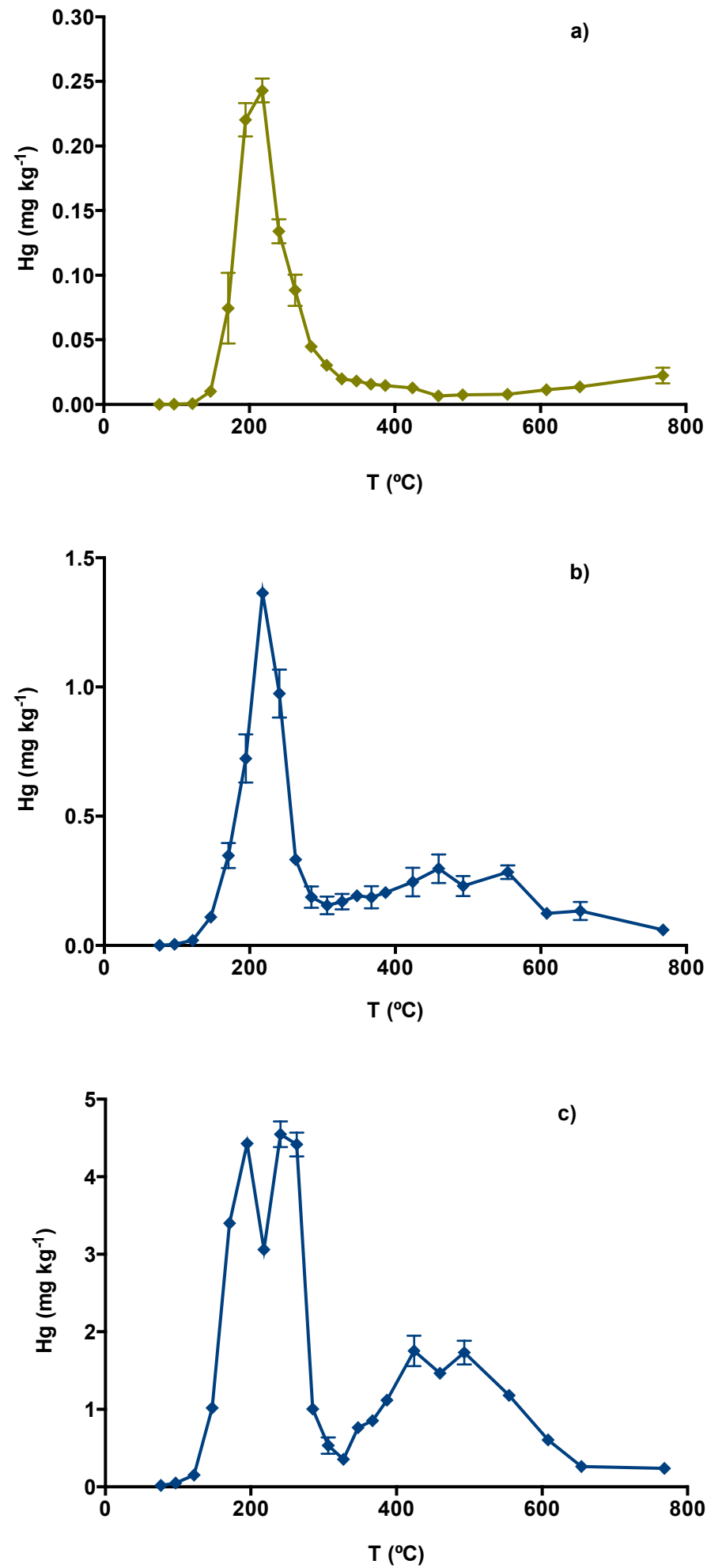
Figure 4
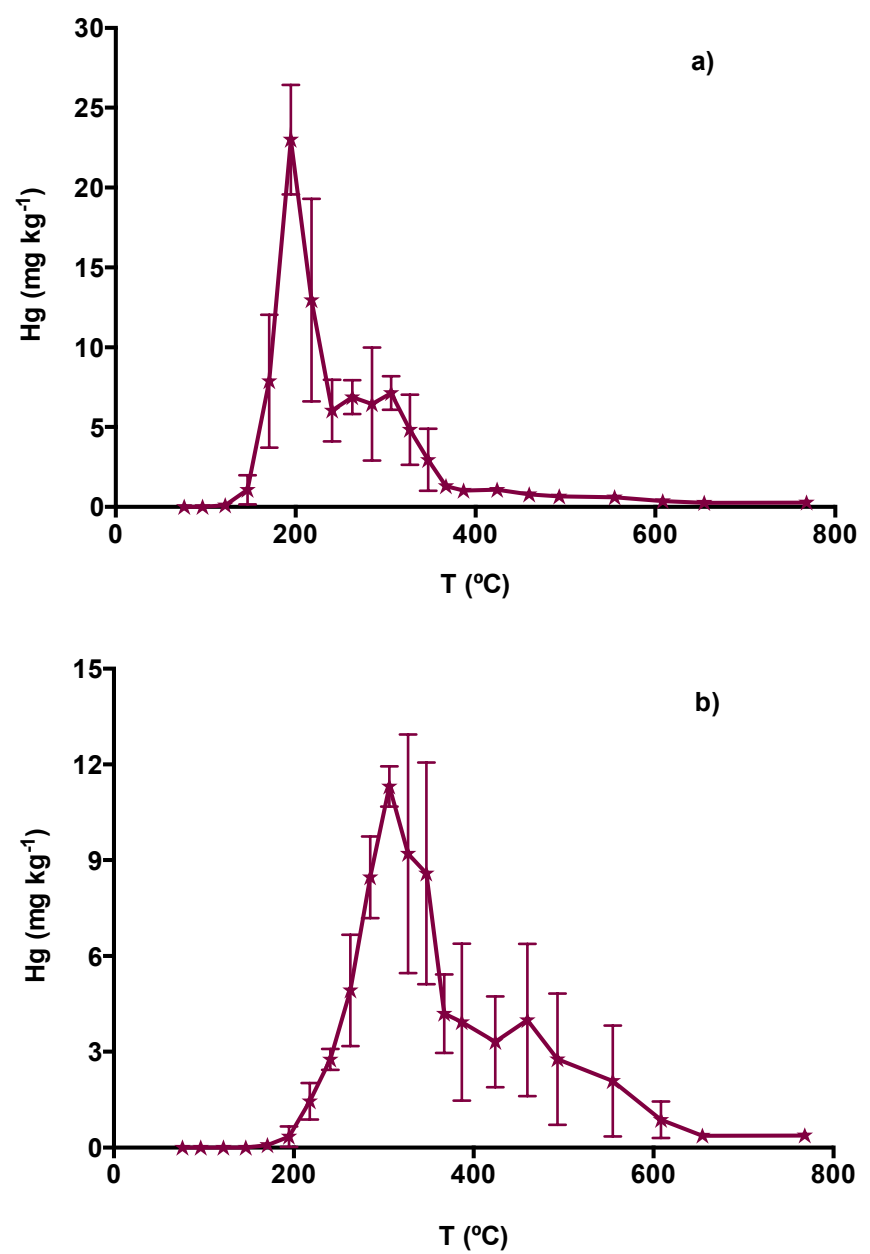
Figure 5

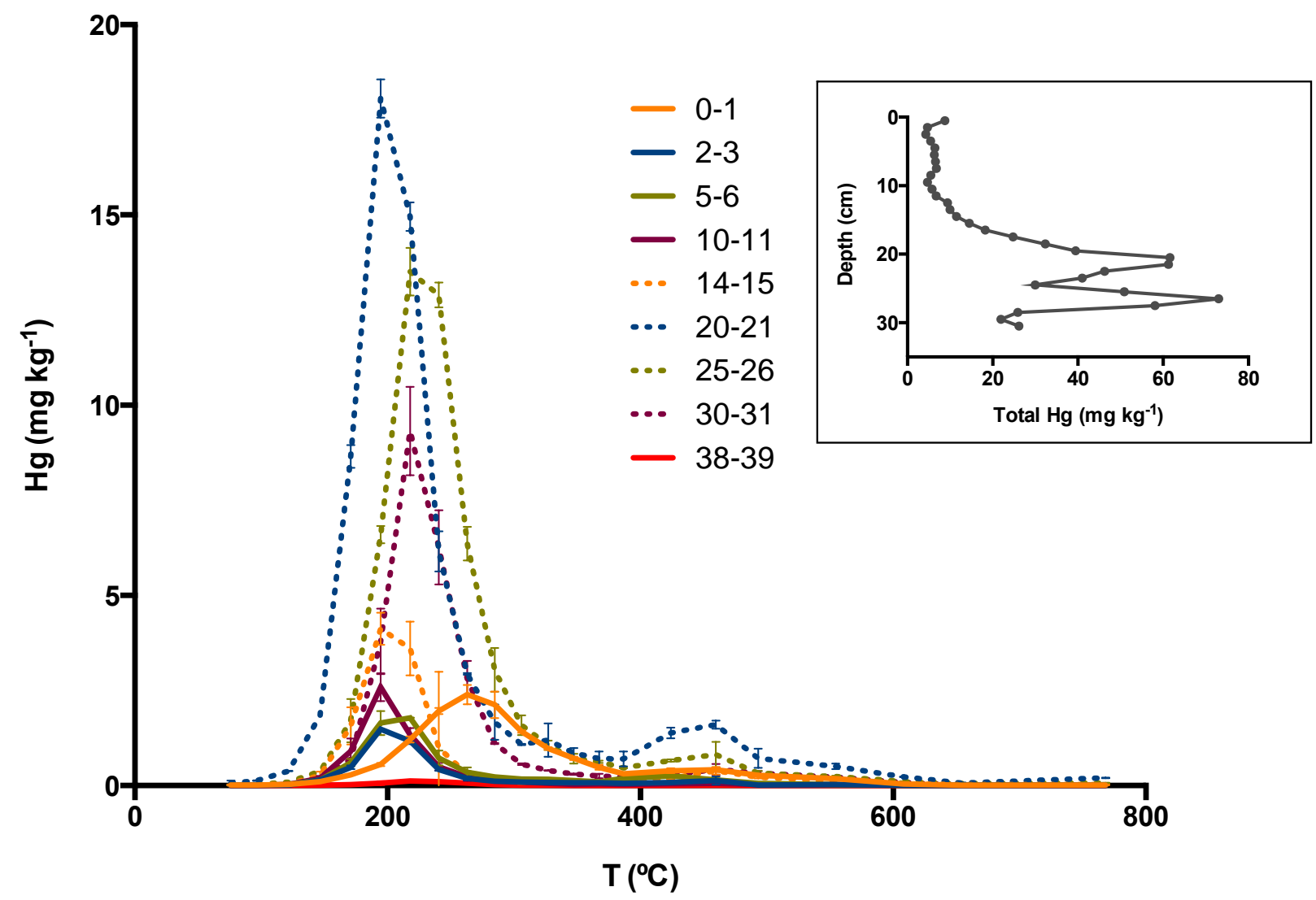


Figure 6
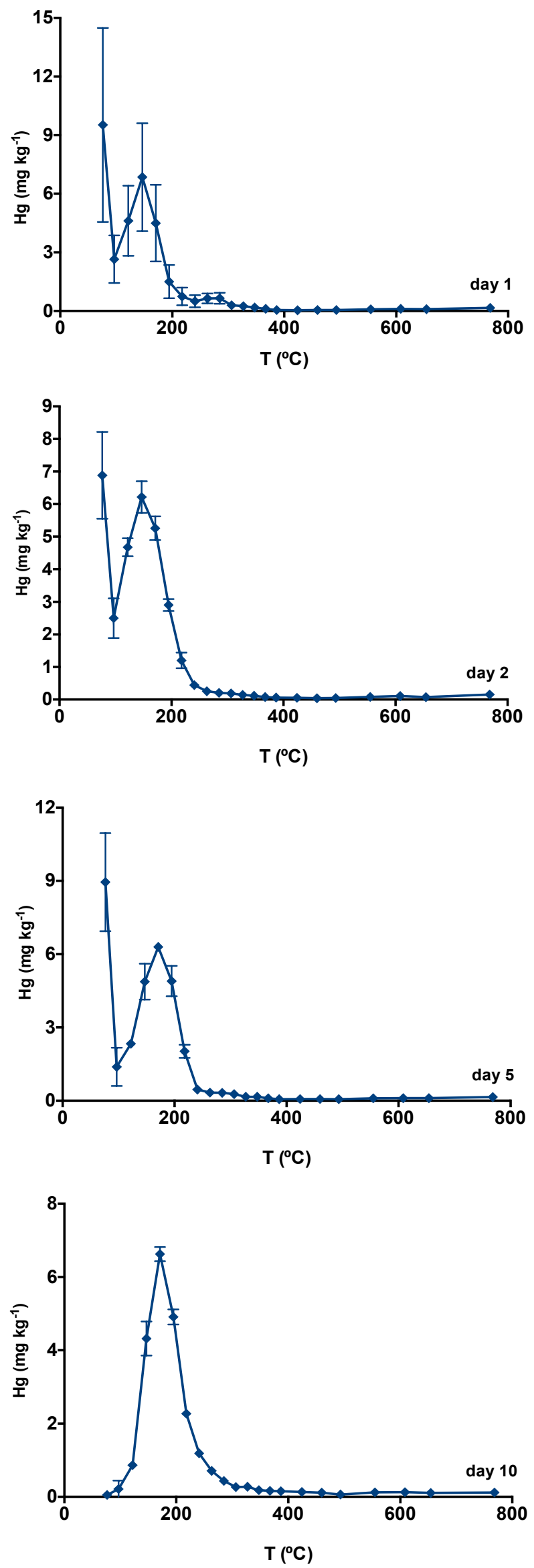